\title{
Ecosystem engineering by large grazers enhances carbon stocks in a tidal salt marsh
}

\author{
Kelly Elschot ${ }^{1, *}$, Jan P. Bakker ${ }^{1}$, Stijn Temmerman ${ }^{2}$, Johan van de Koppel ${ }^{3}$, \\ Tjeerd J. Bouma ${ }^{3}$
}

\author{
${ }^{1}$ Community and Conservation Ecology Group, University of Groningen, PO Box 11103, 9700 CC Groningen, \\ The Netherlands \\ ${ }^{2}$ Ecosystem Management Research Group, University of Antwerp, Universiteitsplein 1, 2610 Wilrijk, Belgium \\ ${ }^{3}$ Spatial Ecology Group, Royal Netherlands Institute for Sea Research (NIOZ-Yerseke), PO Box 140, 4400 AC Yerseke, \\ The Netherlands
}

\begin{abstract}
Grazers can have a large impact on ecosystem processes and are known to change vegetation composition. However, knowledge of how the long-term presence of grazers affects soil carbon sequestration is limited. In this study, we estimated total accumulated organic carbon in soils of a back-barrier salt marsh and determined how this is affected by long-term grazing by both small and large grazers in relation to age of the ecosystem. In young marshes, where small grazers predominate, hare and geese have a limited effect on total accumulated organic carbon. In older, mature marshes, where large grazers predominate, cattle substantially enhanced carbon content in the marsh soil. We ascribe this to a shift in biomass distribution in the local vegetation towards the roots in combination with trampling effects on the soil chemistry. These large grazers thus act as ecosystem engineers: their known effect on soil compaction (based on a previous study) enhances anoxic conditions in the marsh soil, thereby reducing the oxygen available for organic carbon decomposition by the local microbial community. This study showed that the indirect effects of grazing can significantly enhance soil carbon storage through changing soil abiotic conditions. This process should be taken into account when estimating the role of ecosystems in reducing carbon dioxide concentration in the atmosphere. Ultimately, we propose a testable conceptual framework that includes 3 pathways by which grazers can alter carbon storage: (1) through above-ground biomass removal, (2) through alteration of biomass distribution towards the roots and/or (3) by changing soil abiotic conditions that affect decomposition.
\end{abstract}

KEY WORDS: Carbon sequestration · Climate change $\cdot$ Coastal wetland · Grazing · Redox potential $\cdot$ Soil compaction $\cdot$ Succession

\section{INTRODUCTION}

The rapid increase in atmospheric carbon dioxide $\left(\mathrm{CO}_{2}\right)$ concentration may to some extent be counteracted by carbon sequestration in natural ecosystems (Cannell et al. 1999, Janzen 2004, Le Quéré et al. 2009). Wetlands, including coastal marshes, can play an important role as carbon sinks because of the close feedbacks between vegetation, sedimentation and anoxic conditions, promoting carbon storage (Valery et al. 2004, Duarte et al. 2005, Olsen et al.
2011, Kirwan \& Mudd 2012). Once present in the soil, organic carbon can remain buried for a very long time (Connor et al. 2001, Chmura et al. 2003, Duarte et al. 2005, Mcleod et al. 2011). Several studies show that coastal ecosystems, such as tidal marshes, can accumulate a large amount of carbon (Chmura et al. 2003, Duarte et al. 2005, Laffoley \& Grimsditch 2009, Mcleod et al. 2011). So far, studies assessing the role of marshes as carbon sinks have mainly focused on abiotic drivers, including sedimentation rate and global warming (Connor et al. 2001, Kirwan \& Mudd 
2012, Saintilan et al. 2013, Lovelock et al. 2014), whereas biotic drivers, such as grazer presence, have received much less attention (with the exceptions of e.g. Morris \& Jensen 1998, Yu \& Chmura 2009, Olsen et al. 2011).

Marshes are used as feeding grounds by many different grazers, ranging from large populations of migratory birds (e.g. Kerbes et al. 1990, Madsen 1991) to livestock; livestock grazing is used as a nature management tool in many European marshes (e.g. Bakker 1989, Kiehl et al. 1996). Grazers can have a large impact on local carbon sequestration in marshes, but results found so far have been limited and contradictory. For example, in some marshes, they decreased organic carbon accumulation by removing above-ground biomass and thus reducing litter production (Morris \& Jensen 1998). In other marshes, they positively affected organic carbon accumulation by increasing below-ground biomass production (Yu \& Chmura 2009, Olsen et al. 2011) and/or reducing turnover rates (Olsen et al. 2011). Grazing may even turn a marsh from a carbon sink into a carbon source when burrowing crabs increase bioturbation of the soil and remove biomass through grazing (Taylor \& Allanson 1993). These contradictory results suggest that the effects of grazers on organic carbon sequestration can differ between systems and/or grazer type, and further study is required before getting to a general mechanistic understanding.

In the present study, we quantified total accumulated organic carbon during marsh development in a northwestern European back-barrier marsh (Schiermonnikoog) dominated by fine-grained sediment accretion (detailed description in 'Materials and methods'). This back-barrier marsh gives us the unique opportunity to study processes over a long time scale due to gradual expansion of the marsh towards the east, resulting in a natural chronosequence (i.e. from 15 to 120 yr old marshes) going from east to west (Olff et al. 1997). The younger marshes are used by small grazers as feeding grounds, with highest grazing intensity at the approximately 30 yr old marsh (van de Koppel et al. 1996, Elschot et al. 2013). The older, most western marshes are grazed by livestock. Previous studies showed that when marshes become older, palatable plant species become slowly replaced by unpalatable ones (Leendertse et al. 1997, Veeneklaas et al. 2013), and the number of small grazers present within the ecosystem reduces (van der Wal et al. 2000, Bos et al. 2004). At this stage, larger grazers become necessary to set back succession (Bos et al. 2002).
In the younger marshes of Schiermonnikoog, small grazers have been excluded from experimental plots for about $15 \mathrm{yr}$, whereas in the oldest mature marsh, livestock have been excluded for about $20 \mathrm{yr}$ from part of the marsh. The clear gradients in age and grazing type (i.e. small vs. large grazers) as well as longterm exclosure experiments present in the marsh offer an excellent opportunity to quantify the effects of long-term grazing by both small and large grazers on carbon sequestration. Previous studies showed that grazing will not only reduce above-ground biomass but that grazers can also act as ecosystem engineers by increasing the bulk density of the soil layer through trampling (Elschot et al. 2013, Nolte et al. 2013), thereby promoting anoxic conditions and altering the nitrogen cycle (Schrama et al. 2013). Anoxic conditions in the soil are known to reduce the mineralization rate (Aller 1994, Sun et al. 2002, First \& Hollibaugh 2010). Thus, in this study, we included not only the effects of grazing on biomass of the local vegetation but also studied their impact on local abiotic conditions due to potential soil compaction. In this study, we tested 2 hypotheses: (1) in young marshes, small grazers reduce carbon stocks by removing above-ground biomass of the local vegetation, and (2) in older, mature marshes, large grazers will increase carbon stocks due to trampling, which is known to enhance bulk density (Elschot et al. 2013) and expected thereby to promote anoxic conditions and reduce carbon decomposition in the soil.

\section{MATERIALS AND METHODS}

\section{Study site}

This study was carried out on the back-barrier marsh of the island of Schiermonnikoog, The Netherlands, located in the Wadden Sea (Fig. 1, 53 $30^{\prime} \mathrm{N}$, $\left.6^{\circ} 10^{\prime} \mathrm{E}\right)$. The western and oldest marshes (185 ha) are grazed by cattle in summer with a stocking rate of approximately 0.5 ind. ha ${ }^{-1}$ (Bos et al. 2002). The more eastern and younger marshes (1450 ha) have never been grazed by cattle but are very important for small grazers. That is, they are grazed by migratory birds such as barnacle goose Branta leucopsis and Brent goose $B$. bernicla during winter and spring and by European brown hares Lepus europaeus year-round. The highest grazing intensity of geese and hare is found at marshes of intermediate age (van de Koppel et al. 1996, Elschot et al. 2013), where the density of nutritious, palatable species is highest (Olff et al. 1997). Within our study site, we observed 
a
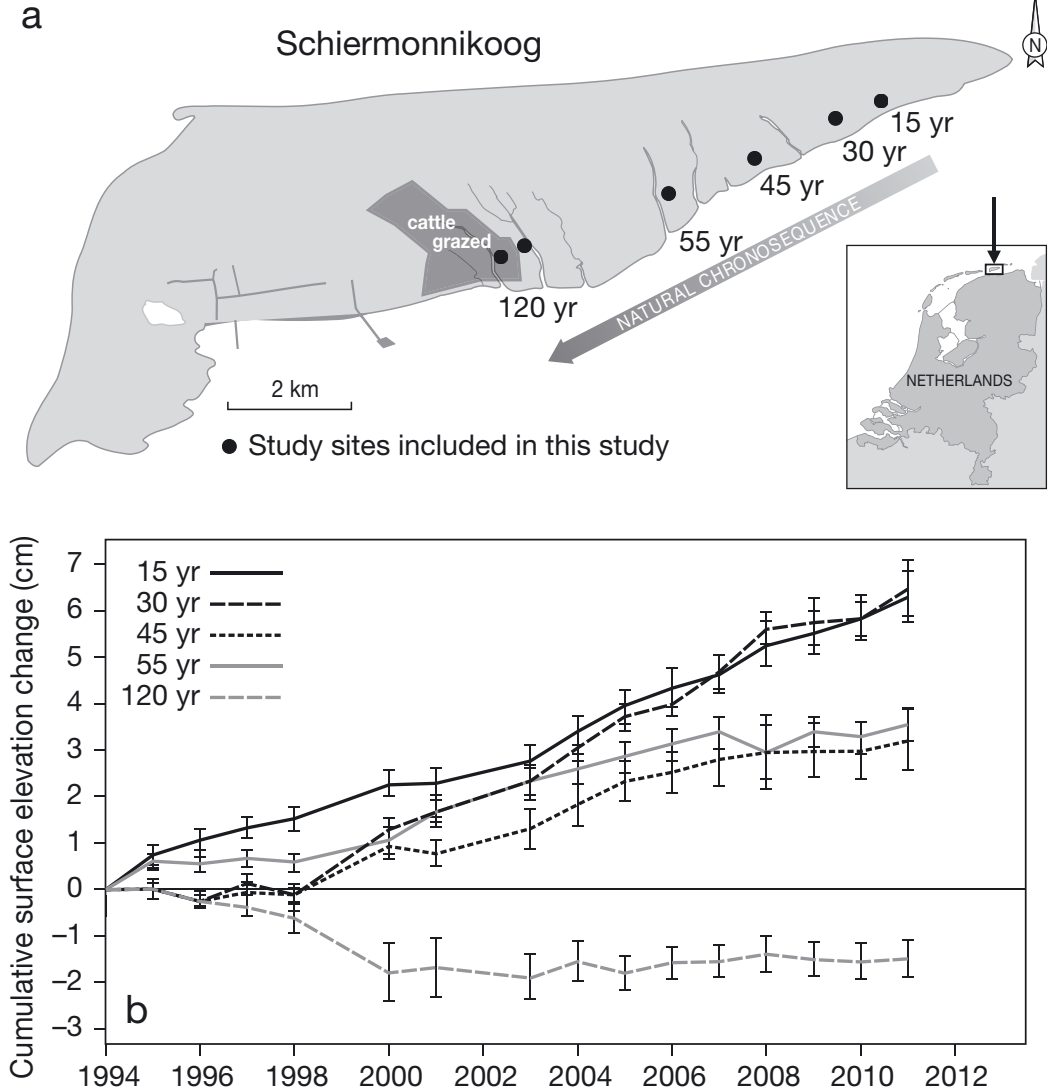

Fig. 1. (a) Back-barrier marsh of Schiermonnikoog, with the natural chronosequence indicated. All sampled locations are indicated by black dots and include approximate ages of each marsh. (b) For each location (indicated by age), the cumulative surface elevation change $(\mathrm{cm})$ between 1994 and 2011 is given. The surface elevation change was not determined in the cattle-grazed marsh al. 1997, Kuijper \& Bakker 2005). The age of each location (i.e. the age since the marsh was formed by plant colonization on an initially bare tidal flat) was determined using time series of aerial photographs (Olff et al. 1997). This led to approximate marsh age estimates of $15,30,45,55$ and $120 \mathrm{yr}$ in 2010 , when we took most of our measurements (Fig. 1a, further details are given by Olff et al. 1997). Within the 4 youngest marsh ages, $7 \times 7 \mathrm{~m}$ grazing exclosures for small grazers were set up in 1994 which excluded grazing by both hares and geese (further details are given by Kuijper \& Bakker 2005). Four exclosures in total (1 exclosure per marsh age) were sampled to test the effects of small grazers. The oldest and fifth location, the $120 \mathrm{yr}$ old marsh, was grazed by cattle until 1958, abandoned between 1958 and 1988 and only partly grazed again afterwards. In this study, we measured on the opposite sides of a cattle-grazed fence to estimate the effects of large grazers. Each measurement was taken at a distance of at least $2 \mathrm{~m}$ from the fence with $2 \mathrm{~m}$ distance between 2 measurement points. Our set-up thus provided a change in plant composition with increasing marsh age. A vegetation type dominated by Puccinellia maritima and Limonium vulgare in young marshes is replaced by a vegetation type dominated by Festuca rubra and Artemisia maritima at marshes of intermediate age (Olff et al. 1997, Bakker et al. 2005). Ultimately, a monoculture of Elytrigia atherica becomes dominant in mature marshes (Veeneklaas et al. 2013, Wanner et al. 2014). Large grazers reduce the cover of $E$. atherica and the cover of younger successional species, such as F. rubra and $P$. maritima, then increases again (Bos et al. 2002). To quantify the impact of grazing on marsh development, a series of grazing exclosures were placed along the age gradient of the marshes in 1994 (details in next section).

\section{Experimental set-up}

Along the chronosequence, 5 locations were selected which differed in age and productivity (Olff et types, albeit in an unbalanced way: about $15 \mathrm{yr}$ with and without small grazers on 15, 30, 45 and $55 \mathrm{yr}$ old marshes vs. about $20 \mathrm{yr}$ with and without large grazers on the $120 \mathrm{yr}$ old marsh.

\section{Net surface elevation change}

Rates of surface elevation change $(\mathrm{cm})$ were quantified by annual measurements using duplicate sedimentation-erosion bars (SEBs) (Boumans \& Day 1993). The SEBs were established in 1994 on each of the locations, outside the exclosures. We did not include the cattle-grazed area. Cattle are attracted by the poles and affect measurements. Each SEB consisted of 3 poles, which were positioned in a triangular shape with a distance of approximately $2 \mathrm{~m}$ between 2 poles. Each pole was embedded at least $1 \mathrm{~m}$ in the underlying sandy substrate to ensure stability over time. An aluminum bar perforated by 17 sampling of marshes of different ages and grazing 
holes placed $10 \mathrm{~cm}$ apart could be placed on top of 2 adjacent SEB poles. A small pin placed through each of the holes allowed estimation of the soil surface elevation to the nearest $0.1 \mathrm{~cm}$. Per SEB triangle, this resulted in $17 \times 3=51$ measurements, which were averaged to obtain the annual surface elevation change for a given SEB location per year between 1994 and 2011.

\section{Soil sampling and lab analyses}

Back-barrier marsh development starts on an initial coarse-grained (sandy) substrate: the base elevation (Olff et al. 1997). Once pioneer vegetation establishes, fine-grained sediment (silt) containing organic carbon accumulates over time on top of the coarsegrained substrate. The sharp border between both sediment types allowed us to exactly sample the total accumulated carbon that has been buried in the finegrained sediment layer since the marsh was formed. At all 5 marsh ages, fine-grained sediment samples were taken inside and outside the grazing exclosure in June 2010. All measurements inside the exclosures were at least $1 \mathrm{~m}$ from the fence to prevent edge effects. Plots outside the exclosure were set up at least $10 \mathrm{~m}$ away from the exclosure at a similar base elevation as the underlying coarse-grained substrate. Having a similar base elevation enables us to identify potential effects of grazing on the thickness of the accreted fine-grained sediment layer, as the underlying coarse-grained substrate is not affected by grazing of the marsh.

Per marsh age, we sampled 10 cores from the entire fine-grained sediment layer present on top of the coarse-grained substrate, 5 cores inside and 5 cores outside the exclosure. The cores were taken throughout the entire exclosure to reduce the chances of any pseudo-replication effect. Total core length was compared with the depth of the hole left in the soil surface to exclude samples that were compacted during sampling. We used a Tullgren soil core $(10 \mathrm{~cm}$ in diameter and $20 \mathrm{~cm}$ in length), which is often used for soil fauna sampling (van Straalen \& Rijninks 1982, Schrama et al. 2012), allowing us to sample with minimal compaction. If compaction was more than $0.5 \mathrm{~cm}$, the core was discarded, and a new one was taken. From each core, 2 slices of $5 \mathrm{~cm}$ were sampled, with the top layer ranging from 0.5 to $5.5 \mathrm{~cm}$ and the deeper layer ranging from 5.5 to $10.5 \mathrm{~cm}$ depth. We included a top and a deeper layer, as we expected to find the largest impact by the grazers in the top soil layer. Only the top layer of sediment has been accreted since the exclosures were placed in 1994, considering an average accretion rate of $3 \mathrm{~mm} \mathrm{yr}^{-1}$ (van Wijnen \& Bakker 1997). Additionally, carbon content can change with soil depth (see e.g. Jobbágy \& Jackson 2000). Only the top layer could be sampled at the youngest marsh age (15 yr) due to a limited fine-grained sediment layer thickness of approximately $7 \mathrm{~cm}$, but we could sample 2 layers at all other marsh ages. There was a distinct difference between the litter layer and the top of the soil layer. The top $0.5 \mathrm{~cm}$ of each core was discarded to avoid the highest root density of the vegetation. To avoid contamination of the fine-grained sediment with coarser sediment, the bottom few centimeters near the underlying coarse-grained substrate were not used for analyses either. Additionally, locally occurring thin coarse-grained layers (generally a few millimeters thick) within the fine-grained sediment layer (de Groot et al. 2011) were avoided. Although these layers might contain carbon as well, the number and thickness of the layers are highly variable and differ between marsh sites (de Groot et al. 2011). The coarse-grained material could increase the bulk density, resulting in a biased organic carbon content found depending on number and sizes of local coarse-grained layers. Additionally, we measured the total fine-grained sediment layer thickness with a smaller corer (diameter $1.5 \mathrm{~cm}) 4$ times in an area of $1 \mathrm{~m}^{2}$ surrounding each sampled core. This led to average finegrained sediment layer thicknesses of $7.0 \pm 0.4$, $10.1 \pm 0.5,14.2 \pm 0.3,13.0 \pm 0.5,12.0 \pm 0.3$ and 11.0 $\pm 0.2 \mathrm{~cm}$ at $15,30,45,55$ and $120 \mathrm{yr}$ old marshes and at the cattle-grazed marsh, respectively (see also Elschot et al. 2013).

From each slice (of $5 \mathrm{~cm}$ thickness), 4 small subcores of known volume (diameter $2.1 \mathrm{~cm}$, volume $16.7 \pm 1.9 \mathrm{~cm}^{3}$ ) were sampled and freeze dried. After freeze drying, dry bulk density $\left(\mathrm{g} \mathrm{cm}^{-3}\right)$ was estimated by weighing all 4 sub-cores and dividing the weight by their volume. Next, one randomly chosen sub-core was used for organic carbon analysis. All large living root fragments were removed using a $1 \mathrm{~mm}$ sieve. From the sieved material, we estimated percentage organic carbon. First, inorganic carbon was removed by in situ acidification with ultra-pure hydrochloric acid. Second, samples were combusted at a very high temperature $\left(1010^{\circ} \mathrm{C}\right)$ with excess oxygen to make sure all carbon present was turned into $\mathrm{CO}_{2}$, which in turn was detected with a thermal conductivity detector (further details are given by Nieuwenhuize et al. 1994). 


\section{Soil redox potential and plant biomass distribution}

In November 2012, we measured the effects of grazing by small and large grazers on soil redox potential $(\mathrm{mV})$ and plant biomass $\left(\mathrm{g} \mathrm{cm}^{-2}\right)$. Due to practical constraints, we included only 2 sites: (1) the $30 \mathrm{yr}$ old marsh, where the intensity of small grazers is highest (van de Koppel et al. 1996, Elschot et al. 2013), and (2) the mature $120 \mathrm{yr}$ old marsh, where the large grazers were excluded. We measured redox potential at $5 \mathrm{~cm}$ depth using 5 platinum electrodes and 1 mercury(I) chloride reference electrode (replicated 15 times). All values estimated with the mercury(I) chloride electrode were converted with the formula $y=1.675 x+$ $23.79 \mathrm{mV}$, which is based on calibration in the lab using a standard hydrogen electrode. Redox potential is used as a proximal measure of soil oxygen content that is potentially available for the decomposition of soil organic carbon (for further information, see van Bochove et al. 2002).

To quantify plant biomass of the local vegetation, we collected small cores $(5 \mathrm{~cm}$ in diameter and $5 \mathrm{~cm}$ in length) inside and outside each exclosure (replicated 10 times). We carefully positioned the cores on the marsh platform to sample both above-ground and below-ground biomass. In the lab, all aboveground biomass was cut from the cores and sorted into dead (litter) and living plant material. The below-ground material was washed over a $1 \mathrm{~mm}$ sieve to remove all sediment. Dead organic material present in the soil that could be identified by eye was removed from the samples. All samples were dried at $70^{\circ} \mathrm{C}$ and then weighed. Additionally, based on the biomass of the living roots and shoots, we calculated the root:shoot ratios (defined as the below-ground living root biomass divided by the above-ground living shoot biomass; Mokany et al. 2006).

\section{Data analyses}

Based on the weight percentage of organic carbon together with the sediment bulk density $\left(\mathrm{g} \mathrm{cm}^{-3}\right)$, we quantified organic carbon content $\left(\mathrm{g} \mathrm{cm}^{-3}\right)$ in both the upper and lower fine-grained sediment layer separately. Then, we assigned the carbon content estimated in the top layer to the top $5 \mathrm{~cm}$ and assigned the carbon content of the deeper layer to the rest of the fine-grained layer. Thus, if we measured a total fine-grained sediment layer of $14 \mathrm{~cm}$ at a specific site, we used $5 \mathrm{~cm}$ for the top layer and $9 \mathrm{~cm}$ for the bottom layer. By adding both calculated values together, we estimated total accumulated organic carbon per unit of marsh surface area $\left(\mathrm{g} \mathrm{cm}^{-2}\right)$. This gave us an approximate value for the total organic carbon present in the soil per soil core.

To test the effects of grazing on carbon sequestration, we used 2-way ANOVAs for the small grazers and $t$-tests for the large grazers. Total carbon accumulated, percentage carbon and carbon content per layer were all analyzed separately. Due to the unbalanced design in this study, we had to analyze the small and large grazer effects separately. For the small grazers, both grazing and marsh age were used as predictor variables. If we found a significant interaction effect between grazing and marsh age, we used a Tukey's HSD test to determine whether grazing had a significant effect per marsh age individually. We used linear regressions to determine whether total organic carbon, percentage carbon or carbon content significantly changed with increasing marsh age. To analyze the effects of grazing on biomass distribution and redox potential, we used 2-way ANOVAs, with grazing and site as predictor variables. These were followed by Tukey's HSD tests. Root biomass and root:shoot ratios were log transformed to account for non-normality. p-values $\leq 0.05$ were considered significant in all analyses. All data were analyzed using $R$, version 2.13.0 (R Development Core Team 2011).

\section{RESULTS}

\section{Net surface elevation change}

Average surface elevation change decreased with marsh age (Fig. 1b). Based on the SEBs, we found that the youngest marshes, 15 and $30 \mathrm{yr}$ old, both increased in surface elevation relatively fast, approximately $6 \mathrm{~cm}$ in $17 \mathrm{yr}$. This equates to an average increase of $0.37 \pm 0.01 \mathrm{~cm} \mathrm{yr}^{-1}$ for the $15 \mathrm{yr}$ old marsh and $0.38 \pm 0.01 \mathrm{~cm} \mathrm{yr}^{-1}$ for the $30 \mathrm{yr}$ old marsh (total surface elevation change divided by the number of years measured). Intermediate-aged marshes, 45 and $55 \mathrm{yr}$ old, had a cumulative surface elevation change of approximately $3 \mathrm{~cm}$. This was an increase of $0.19 \pm$ $0.01 \mathrm{~cm} \mathrm{yr}^{-1}$ for the $45 \mathrm{yr}$ old marsh and $0.21 \pm$ $0.01 \mathrm{~cm} \mathrm{yr}^{-1}$ for the $55 \mathrm{yr}$ old marsh. The oldest location, $120 \mathrm{yr}$ old, showed a negative surface elevation change and decreased 1 to $2 \mathrm{~cm}$ between 1994 and 2000. The elevation remained relatively stable between 2000 and 2011 (Fig. 1b). 

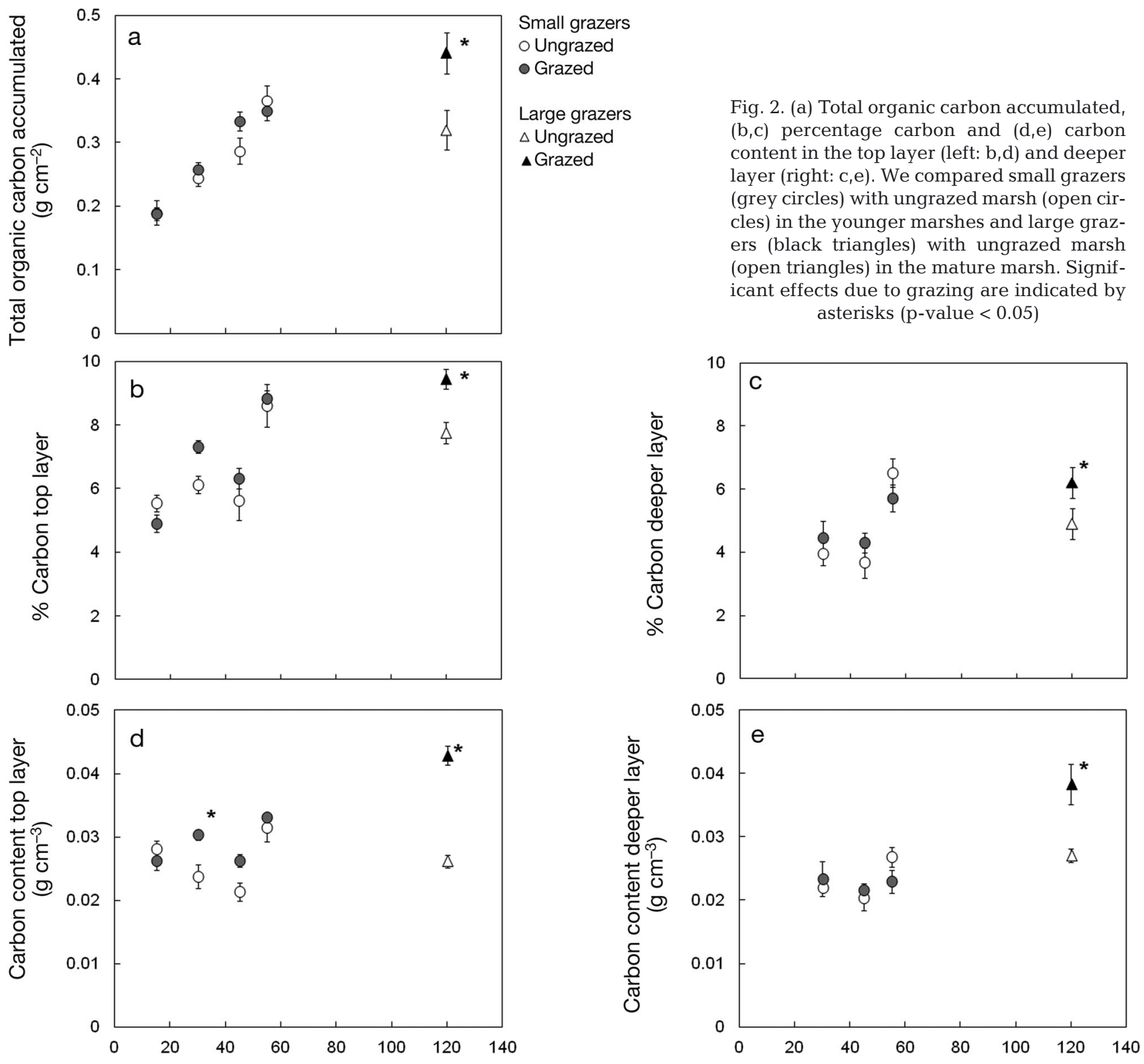

Marsh age (yr)

\section{Effects of age on organic carbon sequestration}

Total organic carbon $\left(\mathrm{g} \mathrm{cm} \mathrm{cm}^{-2}\right.$, organic carbon accumulated per unit soil surface) increased significantly with marsh age $\left(t_{38}=11.1\right.$, adjusted $\mathrm{R}^{2}=0.76$, $\mathrm{p}<0.001$, Fig. 2a). However, the carbon accumulation stabilized at about $0.33 \mathrm{~g} \mathrm{~cm}^{-2}$ once the marsh was approximately $45 \mathrm{yr}$ old (Fig. 2a). The carbon accretion rate was highest at the youngest marsh, approximately $12.6 \pm 0.9 \times 10^{-3} \mathrm{~g} \mathrm{~cm}^{-2} \mathrm{yr}^{-1}$ at the $15 \mathrm{yr}$ old marsh (total accumulated carbon divided by marsh age). This sequestration rate decreased rapidly with marsh age (Fig. 2a), ranging from $8.3 \pm$
$0.4 \times 10^{-3} \mathrm{~g} \mathrm{~cm}^{-2} \mathrm{yr}^{-1}$ at the $30 \mathrm{yr}$ old marsh, $6.9 \pm$ $0.4 \times 10^{-3} \mathrm{~g} \mathrm{~cm}^{-2} \mathrm{yr}^{-1}$ at the $45 \mathrm{yr}$ old marsh and 6.5 $\pm 0.3 \times 10^{-3} \mathrm{~g} \mathrm{~cm}^{-2} \mathrm{yr}^{-1}$ at the $55 \mathrm{yr}$ old marsh down to $2.7 \pm 0.1 \times 10^{-3} \mathrm{~g} \mathrm{~cm}^{-2} \mathrm{yr}^{-1}$ at the $120 \mathrm{yr}$ old marsh. The percentage carbon increased significantly with marsh age in both the top layer $\left(t_{38}=\right.$ 5.4 , adjusted $\mathrm{R}^{2}=0.42, \mathrm{p}<0.001$ ) and the deeper layer $\left(t_{28}=3.4\right.$, adjusted $\left.\mathrm{R}^{2}=0.26, \mathrm{p}<0.01\right)$ (Fig. 2b,c). In contrast, organic carbon content per soil volume $\left(\mathrm{g} \mathrm{cm}^{-3}\right)$ was not linearly related to marsh age in both the top layer $\left(t_{38}=1.5\right.$, adjusted $\left.\mathrm{R}^{2}=0.03, \mathrm{p}=0.14\right)$ and the deeper layer $\left(t_{28}=1.0\right.$, adjusted $\mathrm{R}^{2}=0.0, \mathrm{p}=0.34$ ) (Fig. $2 \mathrm{~d}, \mathrm{e}$ ). 
Table 1. Effects of grazing on carbon sequestration. The effects of small grazers were tested with ANOVAs, and the effects of large grazers were tested with 2 -sample $t$-tests. The models were simplified when interaction effects were not significant. p-values $<0.05$ were considered significant and are indicated in bold. ns: not significant

\begin{tabular}{|c|c|c|c|c|c|c|c|c|c|c|c|c|}
\hline & \multicolumn{3}{|c|}{ Age } & \multicolumn{3}{|c|}{$\begin{array}{c}\text { - Small grazers - } \\
\text { Grazing }\end{array}$} & \multicolumn{3}{|c|}{ Age $\times$ Grazing } & \multicolumn{3}{|c|}{$\begin{array}{l}\text { Large grazers } \\
\text { Grazing }\end{array}$} \\
\hline & $\mathrm{df}$ & $F$ & $\mathrm{p}$ & df & $F$ & $\mathrm{p}$ & $\mathrm{df}$ & $F$ & $\mathrm{p}$ & df & $t$ & $\mathrm{p}$ \\
\hline Total organic carbon accumulated $\left(\mathrm{g} \mathrm{cm}^{-2}\right)$ & 3,35 & 39.5 & $<0.001$ & 1,35 & 1.3 & 0.26 & & ns & & 8.0 & 6.05 & $<0.001$ \\
\hline$\%$ Carbon top layer & 3,35 & 26.8 & $<0.001$ & 1,35 & 1.6 & 0.22 & & ns & & 7.9 & 3.62 & $<0.01$ \\
\hline \% Carbon deeper layer & 2,26 & 14.3 & $<0.001$ & 1,26 & 0.1 & 0.76 & & ns & & 5.5 & 2.47 & $<0.05$ \\
\hline Carbon content top layer $\left(\mathrm{g} \mathrm{cm}^{-3}\right)$ & 3,32 & 12.7 & $<0.001$ & 1,32 & 8.2 & $<0.01$ & 3,32 & 3.6 & 0.02 & 7.1 & 9.49 & $<0.001$ \\
\hline Carbon content deeper layer $\left(\mathrm{g} \mathrm{cm}^{-3}\right)$ & 2,26 & 2.5 & 0.10 & 1,26 & 0.1 & 0.79 & & ns & & 5.0 & 3.36 & 0.02 \\
\hline
\end{tabular}

\section{Effects of grazing on organic carbon sequestration}

The small grazers did not significantly affect total organic carbon accumulated (Fig. 2a) or percentage carbon (Fig. 2b,c); statistics are given in Table 1. The only significant effect by the small grazers was a small increase in organic carbon content at the $30 \mathrm{yr}$ old marsh in the top layer (Fig. 2d). Large grazers increased the total organic carbon accumulated in the soil substantially, increasing it from $0.32 \pm 0.01 \mathrm{~g}$ $\mathrm{cm}^{-2}$ in the ungrazed marsh to $0.44 \pm 0.01 \mathrm{~g} \mathrm{~cm}^{-2}$ in the grazed marsh (Fig. 2a), i.e. adding more than a kilogram of carbon to the soil per square meter at the $120 \mathrm{yr}$ old marsh. The presence of large grazers on the 120 yr old marsh significantly increased percentage carbon (\%) and carbon content $\left(\mathrm{g} \mathrm{cm}^{-3}\right)$ in both the top and the deeper fine-grained sediment layer (Fig. 2b-e).

\section{Redox potential and plant biomass distribution}

Both small and large grazers reduced the redox potential significantly (Fig. 3a, Table 2). The significant interaction effect between grazing and age (Table 2) implies that the effect of large grazers is much more substantial than the effect of small graz- ers (Fig. 3a). Additionally, the redox potential was significantly lower in the mature (120 yr old) marsh compared to the younger (30 yr old) marsh site. Small grazers had no effect on the biomass distribution of the local vegetation (Fig. 3b-d), except for a significant reduction in litter (Fig. 3e). Large grazers altered the biomass allocation by reducing aboveground biomass (Fig. 3b), increasing below-ground biomass (Fig. 3c) and reducing litter (Fig. 3e) significantly. The total living biomass was not significantly affected by the presence of either small or large grazers and was not significantly different between both sites (Fig. 3d). The root:shoot ratio was unaffected by the small grazers and was similar between both marsh sites but increased significantly when large grazers were present (Fig. 3f).

\section{DISCUSSION}

Our results showed that grazers can have a large impact on carbon sequestration in a salt marsh ecosystem. We reject the first hypothesis, that in young marshes, small grazers reduce carbon stocks by removing above-ground biomass of the local vegetation, as we found no effect of small grazers on total carbon stocks. We accept the second hypothesis, that

Table 2. Effects of grazing on biomass distribution and redox potential tested with ANOVAs. The models were simplified when interaction effects were not significant. p-values $\leq 0.05$ were considered significant and are indicated in bold. ns: not significant

\begin{tabular}{|c|c|c|c|c|c|c|c|c|}
\hline & \multicolumn{2}{|r|}{ Grazing } & \multicolumn{3}{|c|}{ Site } & \multicolumn{3}{|c|}{ Grazing $\times$ Site } \\
\hline & $\mathrm{df}$ & $F$ & df & $F$ & $\mathrm{p}$ & $\mathrm{df}$ & $F$ & $\mathrm{p}$ \\
\hline Redox potential (mV) & 1,56 & $129.2<\mathbf{0 . 0 0 1}$ & 1,56 & 400.3 & $<0.001$ & 1,56 & 49.8 & $<0.001$ \\
\hline Below-ground biomass $\left(\mathrm{g} \mathrm{cm}^{-3}\right)$ & 1,37 & $25.7<0.001$ & 1,37 & 13.3 & $<0.001$ & & ns & \\
\hline Above-ground biomass $\left(\mathrm{g} \mathrm{cm}^{-3}\right)$ & 1,36 & $24.0<0.001$ & 1,36 & 26.1 & $<0.001$ & 1,36 & 3.6 & 0.06 \\
\hline Litter $\left(\mathrm{g} \mathrm{cm}^{-3}\right)$ & 1,37 & $18.3<\mathbf{0 . 0 0 1}$ & 1,37 & 4.0 & 0.05 & & ns & \\
\hline Total living biomass $\left(\mathrm{g} \mathrm{cm}^{-3}\right)$ & 1,37 & $0.8 \quad 0.37$ & 1,37 & 2.6 & 0.11 & & ns & \\
\hline Root:shoot ratio & 1,36 & $80.8<\mathbf{0 . 0 0 1}$ & 1,36 & 70.1 & $<0.001$ & 1,36 & 27.6 & $<0.001$ \\
\hline
\end{tabular}



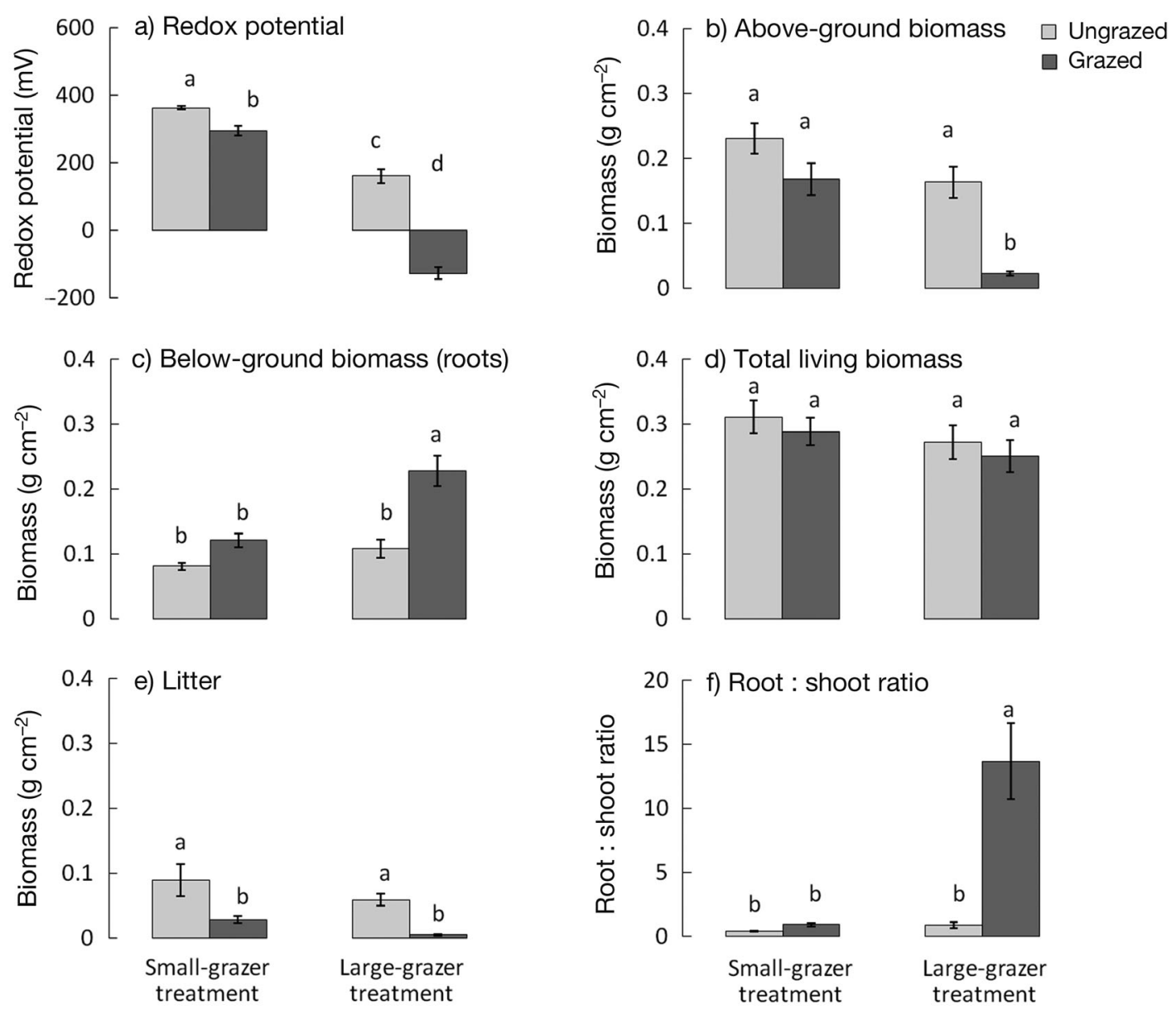

Fig. 3. Differences in (a) redox potential and biomass distribution divided in (b) shoots, (c) roots, (d) total (living) biomass, (e) litter and (f) root:shoot ratios between grazed and ungrazed marsh for small grazers (left) and large grazers (right). Based on Tukey's HSD tests, we assigned different letters when treatments were significantly different ( $p$-value $\leq 0.05$ )

in older, mature marshes, large grazers increased carbon stocks due to trampling, which has been shown to enhance bulk density (Elschot et al. 2013) and was expected to thereby promote anoxic conditions in the soil, as we found a large increase in carbon stocks and a reduction in redox potential in mature marshes. Previous studies assessing the effect of grazers on carbon sequestration showed that they limit carbon storage by removing above-ground biomass (Morris \& Jensen 1998, Sjögersten et al. 2008, Cahoon et al. 2012). However, we found that the indirect effects of grazing (for instance, by altering biomass distribution of the vegetation towards the roots and through compaction of the soil, thereby enhancing anoxic conditions) can outweigh the direct effects of removal of above-ground biomass (Fig. 4). This leads to increased carbon accumulation when large grazers were present. It is generally known that anoxic conditions in the soil will limit mineralization rates by the microbial community
(Aller 1994, Sun et al. 2002, First \& Hollibaugh 2010). Therefore, next to above-ground biomass removal and altering biomass distribution in the vegetation towards the roots, we propose that grazers can alter carbon storage via a third important pathway: by compacting the soil, thereby reducing the mineralization rate, enhancing carbon storage and thus acting as an ecosystem engineer (Fig. 4).

\section{Effects of large grazers on soil carbon stocks}

This study showed that large grazers had a strong positive effect on carbon accumulation. So far, contradicting results have been reported for the effect of large grazers on carbon sequestration in coastal marshes (Taylor \& Allanson 1993, Morris \& Jensen 1998, Yu \& Chmura 2009, Olsen et al. 2011). An empirical study in 2009 based on sheep grazing showed a local increase in both bulk density and 


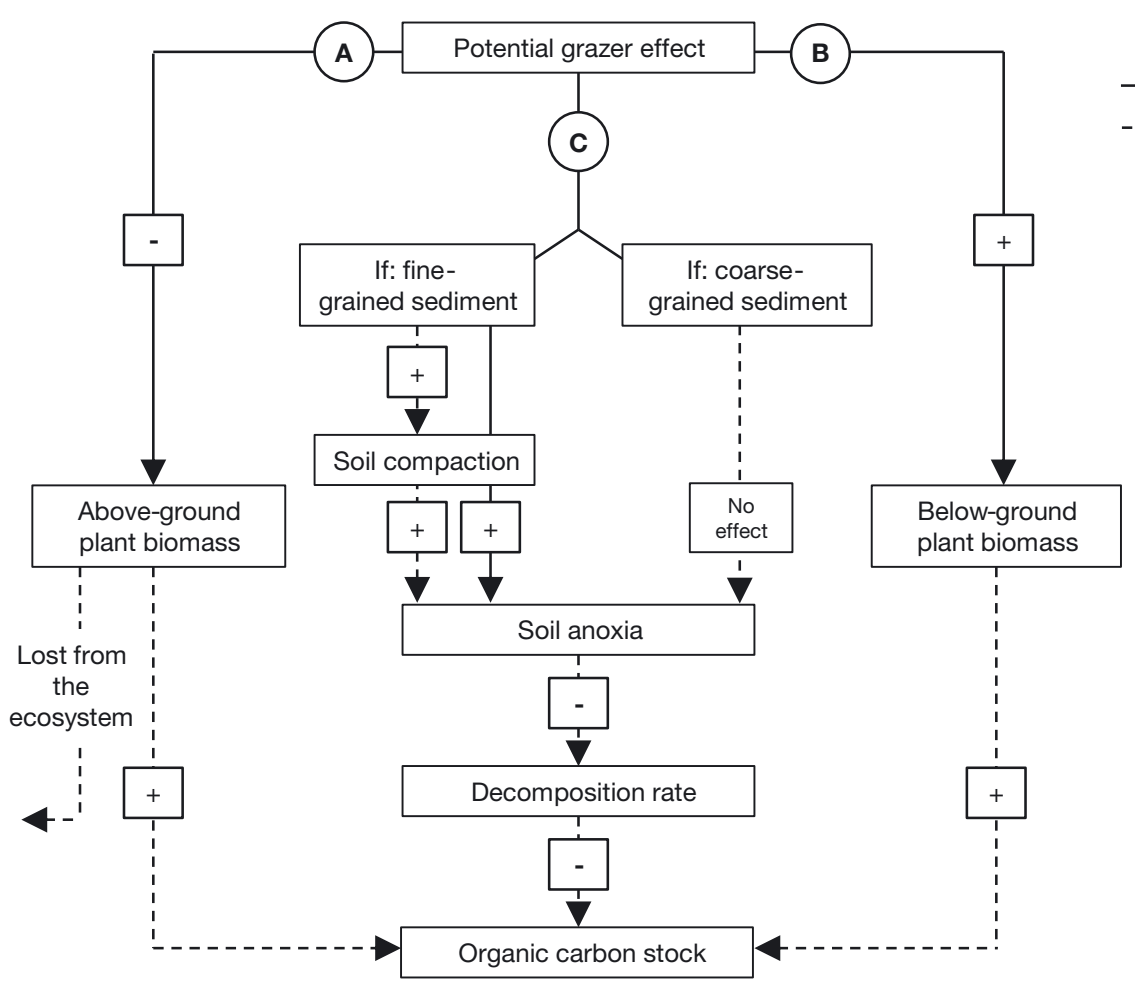

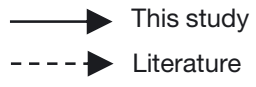

Fig. 4. Testable conceptual framework including 3 pathways by which large grazers can alter carbon storage in salt marshes: $A$, above-ground biomass removal; B, alteration of biomass distribution towards the roots; and/or $\mathrm{C}$, changing the abiotic conditions of the soil by trampling organic carbon (Yu \& Chmura 2009). This is in line with the results found in the present study. In contrast, cattle grazing on Danish marshes negatively affected organic carbon content (Morris \& Jensen 1998), which was attributed to a direct result of above-ground biomass removal by large grazers. The results of our study reveal that large grazers can have an important positive effect on carbon accumulation in marshes.

When negative direct effects by above-ground biomass removal are less substantial than positive indirect effects caused by (1) altered plant biomass distribution towards below-ground root biomass (Zimmerman et al. 1996, Knapp et al. 2008, Cahoon et al. 2012) and (2) changing local soil conditions that reduce carbon decomposition, grazers will enhance carbon sequestration in ecosystems. We propose that soil texture is an important determinant for which effect grazers have within an ecosystem (Fig. 4). Compaction of the soil and subsequent changing soil abiotic conditions will be more substantial in ecosystems with fine-grained (clay and silt) and/or organic-rich (peat) soils and are less likely to occur in ecosystems with more coarse-grained, sandy soils (Fig. 4, Schrama et al. 2013). Ecosystem engineers are defined as 'organisms that directly or indirectly modulate the availability of resources to other species, by causing physical state changes in biotic or abiotic materials' (Jones et al. 1994). Therefore, we can conclude that large grazers can act as ecosystem engineers in ecosystems with fine-grained soils through trampling, thereby compacting the soil and altering carbon decomposition.

Above-ground biomass and litter were lower, but below-ground biomass was higher when large grazers were present (Fig. 3b,c). That grazing-tolerant species invest more energy in their root system compared to above-ground plant parts has been shown in other ecosystems as well (McNaughton et al. 1998, Yu \& Chmura 2009, Olsen et al. 2011, Sjögersten et al. 2012). In coastal marshes, below-ground biomass is likely more important as an organic carbon source than above-ground biomass or litter. Most aboveground material will be easily exported as litter towards coastal waters during high tides and storms (Boschker et al. 1999). Additionally, a large part of the organic carbon input is supplied by the inundating water (Boschker et al. 1999) that contains suspended organic matter from non-local macrophytes, benthic microalgae and phytoplankton (Middelburg \& Nieuwenhuize 1998). Ultimately, we conclude that grazing increased organic carbon input by increased below-ground biomass production and by reduced decomposition as a consequence of trampling and soil compaction and resulting in increased anoxic conditions in the soil (Fig. 4). 


\section{Effects of small grazers on soil carbon stocks}

In contrast to other studies showing the negative effects of small grazers on carbon stocks (van der Wal et al. 2007, Sjögersten et al. 2012), we found no significant effect, except for a small increase in organic carbon content $\left(\mathrm{g} \mathrm{cm}^{-3}\right)$ in the top layer at the $30 \mathrm{yr}$ old marsh (Fig. 2d). According to van de Koppel et al. (1996) and Elschot et al. (2013), grazing densities of hare and geese were highest at marshes of intermediate age, namely, at the $30 \mathrm{yr}$ old marsh. This could explain why we only found effects by small grazers at this marsh age. Based on an average surface elevation change of $0.38 \mathrm{~cm} \mathrm{yr}^{-1}$ (Fig. 1b), only the top layer of the soil contains sediment accreted since the exclosures were placed on the marsh. Therefore, the largest effect of grazer presence should be found in the top layer. Bulk densities of the soil $\left(\mathrm{g} \mathrm{cm}^{-3}\right)$ in both the top and the deeper layer were unaffected by the long-term presence of small grazers (Elschot et al. 2013); hence, the small increase in carbon content is not explained by compaction of the soil layer. We found a small significant reduction in redox potential (Fig. 3a) and a nonsignificant increase in below-ground root biomass (Fig. 3c). Together, they could explain the small increase found in the organic carbon content in the top layer of the fine-grained sediment layer due to the small grazers. Overall, the small increase found was not substantial enough to affect the total carbon stocks quantified in this study.

\section{Effects of age on carbon sequestration}

Carbon storage in the marsh soil is strongly related to marsh age (Fig. 2a). At the youngest marshes, both surface elevation change (Fig. 1b) and the increase in per square meter organic carbon accumulation (Fig. 2a) were highest. A large part of the carbon that accumulates in mineral-based marshes is deposited together with the incoming fine-grained sediment (Boschker et al. 1999). In young marshes, the sediment input is highest (van Wijnen \& Bakker 2001), and high saline, anoxic conditions will limit organic carbon decomposition (Hemminga et al. 1991, Aller 1994). With increasing marsh age, the marsh platform increases in elevation (van Wijnen \& Bakker 2001), resulting in a reduced sediment deposition rate (Allen 2000) and alleviation of the stressful environmental conditions (Bakker et al. 2005, Davy et al. 2011). At the oldest marsh, the marsh platform did not increase in elevation anymore (a negative surface elevation change is even shown), and organic carbon content per square meter was no longer increasing. The negative surface elevation change found at the 120 yr old marsh is likely the result of autocompaction, a natural process that occurs in older, mature marshes, especially after long-term periods of drought (Allen 2000, Bartholdy et al. 2010, Cahoon et al. 2011). At the mature marsh, the total carbon stocks no longer increased. Therefore, we can conclude that the organic matter input from the inundating water together with the local vegetation vs. the output through decomposition has stabilized. Introducing large grazers at this point will increase carbon stocks.

Another potential explanation is a change in vegetation composition with marsh age (Olff et al. 1997, Davy et al. 2011). A study by Jobbágy \& Jackson (2000) showed that vegetation type can have a large impact on soil organic carbon through different biomass allocation patterns. This could explain the difference in carbon stocks found in this study. However, biomass allocation of the local vegetation was not significantly different between young marsh and mature marsh (Fig. 4). The positive correlation we found between carbon stock and marsh age is most likely due to continuous burial of organic carbon that is deposited on the marsh surface during high tides, together with root material of the local vegetation, and not due a change in vegetation composition.

We found that the carbon sequestration rate ( $g$ $\mathrm{cm}^{-2} \mathrm{yr}^{-1}$ ) reduces with age of the marsh and that carbon stocks stabilized when marshes reached $45 \mathrm{yr}$ of age. Most studies estimating organic carbon sequestration in coastal wetlands generally do not take age of the ecosystem into account (e.g. Connor et al. 2001, Chmura et al. 2003, Mcleod et al. 2011). In line with our results, a study in riverine floodplains showed that soil organic carbon accumulated rapidly at young successional stages but that sequestration rate reduced with increasing age and stabilized after approximately $100 \mathrm{yr}$ (Zehetner et al. 2009). They found sequestration rates of $180 \mathrm{~g}$ $\mathrm{m}^{-2} \mathrm{yr}^{-1}$ over the first $25 \mathrm{yr}$ and $100 \mathrm{~g} \mathrm{~m}^{-2} \mathrm{yr}^{-1}$ over $100 \mathrm{yr}$. In comparison, we found a rate of $126 \mathrm{~g} \mathrm{~m}^{-2}$ $\mathrm{yr}^{-1}$ over $15 \mathrm{yr}$ and $27 \mathrm{~g} \mathrm{~m}^{-2} \mathrm{yr}^{-1}$ over $120 \mathrm{yr}$, which is lower than the average rate of $210 \mathrm{~g} \mathrm{~m}^{-2} \mathrm{yr}^{-1}$ as was estimated for salt marshes in general (Chmura et al. 2003). Our accretion rates are lower, which could be explained by the low sedimentation rates found on European back-barrier marshes (van Wijnen \& Bakker 1997) compared to mainland marshes (Nolte et al. 2013). Other studies that estimated car- 
bon sequestration rates along natural chronosequences in wetlands found that the percentage carbon in the soil increased with age of the ecosystem (Cornell et al. 2007, Osland et al. 2012, Lunstrum \& Chen 2014). However, most of these studies had limited chronosequences of approximately $30 \mathrm{yr}$, and the ecosystems might not have reached a stable state yet (e.g. Craft et al. 2003, Cornell et al. 2007, Osland et al. 2012). Coastal wetlands are now recognized as ecosystems that can store large amounts of carbon (Chmura et al. 2003); therefore, it is important to understand which factors control carbon accumulation in these ecosystems. Further studies that include long-term chronosequences, ranging over centuries, will be necessary to determine whether carbon accumulation changes with age.

\section{Pseudo-replication}

This experiment gave us the unique opportunity to study the long-term effects of grazing on carbon sequestration. However, we do need to address the potential problem of pseudo-replication. As only one exclosure per site was sampled, this could result in samples not being completely independent from one another. The exclosures were of a relative large size $(7 \times 7 \mathrm{~m})$, however, which allowed us to spatially spread the samples throughout each exclosure to minimize any pseudo-replication effect from samples taken too close together. The effects of large grazers on carbon sequestration and redox potential as well as biomass distribution were so profound that we consider the results to be robust. However, as we only tested the effects of large grazers on one marsh site, this study should be replicated in more marshes to determine whether this is in fact a general mechanism. The minimal effects we found on the $30 \mathrm{yr}$ old marsh by small grazers on carbon content and redox potential as well biomass distribution need further investigation. We consider the effects of small grazers on total carbon accumulated to be robust, as all 4 sites showed the same result: namely, that small grazers had no significant effect on the total carbon accumulated.

\section{Implications for management}

Our results imply that because we can manage livestock grazing in many ecosystems, it being a well-used management tool in European marshes
(Dijkema 1990, Esselink et al. 2009), we can manage and enhance carbon stocks in mature marshes and potentially in other terrestrial ecosystems (Sjögersten et al. 2012). However, the balance between indirect and direct effects due to grazers needs to be determined in each individual ecosystem independently. Due to current anthropogenic disturbances, natural grazers - especially the large ones - are reduced in numbers in many ecosystems (e.g. de Visser et al. 2011), and climate change is expected to further increase species loss (Thomas et al. 2004, Bellard et al. 2012). When the direct effects of biomass removal is the predominant grazing effect, increased grazing intensity in well-drained sandy grassland systems such as savannas could decrease carbon sequestration. However, trampling by large grazers will most likely increase local carbon sequestration, and this may be the predominant effect in wetland ecosystems such as marshes with fine-grained soils. Although our results are limited to a single barrier island, the mechanisms are potentially general and justify testing in other ecosystems with different grazer species and soil types (Fig. 4). Improving our understanding of the effect of grazers on carbon sequestration may allow us not only to control but also to enhance the ability of ecosystems to act as carbon sinks.

Acknowledgements. We thank Harm van Wijnen and René van der Wal for installing the exclosures in 1994. We acknowledge Natuurmonumenten and Elske Koppenaal for assistance in the field. We thank Maarten Schrama and 2 anonymous reviewers for useful comments on this manuscript, Josephine Cleyndert for assistance in the lab and Dick Visser for preparing the graphs. This study was made possible with funding from the NWOZKO (project 83908320), the Dutch organization for scientific research.

\section{LITERATURE CITED}

Allen JRL (2000) Morphodynamics of Holocene salt marshes: a review sketch from the Atlantic and southern North Sea coasts of Europe. Quat Sci Rev 19:1155-1231

Aller RC (1994) Bioturbation and remineralization of sedimentary organic matter: effects of redox oscillation. Chem Geol 114:331-345

Bakker JP (1989) Nature management by grazing and cutting: on the ecological significance of grazing and cutting regimes applied to restore former species-rich grassland communities in the Netherlands. Kluwer, Dordrecht

> Bakker JP, Bouma TJ, van Wijnen HJ (2005) Interactions between microorganisms and intertidal plant communities. In: Kristensen E, Haese RR, Kostka JE (eds) Interactions between macro- and microorganisms in marine sediments. American Geophysical Union, Washington, DC, p 179-198, doi:10.1029/CE060p0179 
Bartholdy J, Pedersen JBT, Bartholdy AT (2010) Autocompaction of shallow silty salt marsh clay. Sediment Geol 223:310-319

Bellard C, Bertelsmeier C, Leadley P, Thuiller W, Courchamp F (2012) Impacts of climate change on the future of biodiversity. Ecol Lett 15:365-377

Bos D, Bakker JP, de Vries Y, van Lieshout S (2002) Longterm vegetation changes in experimentally grazed and ungrazed back-barrier marshes in the Wadden Sea. Appl Veg Sci 5:45-54

Bos D, van de Koppel J, Weissing FJ (2004) Dark-bellied Brent geese aggregate to cope with increased levels of primary production. Oikos 107:485-496

Boschker HTS, de Brouwer JFC, Cappenberg TE (1999) The contribution of macrophyte-derived organic matter to microbial biomass in salt-marsh sediments: stable carbon isotope analysis of microbial biomarkers. Limnol Oceanogr 44:309-319

Boumans RMJ, Day JW (1993) High precision measurements of sediment elevation in shallow coastal areas using a sedimentation-erosion table. Estuaries 16:375-380

Cahoon DR, Perez BC, Segura BD, Lynch JC (2011) Elevation trends and shrink-swell response of wetland soils to flooding and drying. Estuar Coast Shelf Sci 91:463-474

> Cahoon SMP, Sullivan PF, Post E, Welker JM (2012) Large herbivores limit $\mathrm{CO}_{2}$ uptake and suppress carbon cycle responses to warming in West Greenland. Glob Change Biol 18:469-479

Cannell MGR, Milne R, Hargreaves KJ, Brown TAW and others (1999) National inventories of terrestrial carbon sources and sinks: the UK experience. Clim Change 42: 505-530

> Chmura GL, Anisfield SC, Cahoon DR, Lynch JC (2003) Global carbon sequestration in tidal, saline wetland soils. Global Biogeochem Cycles 17:1111

> Connor RF, Chmura GL, Beecher CB (2001) Carbon accumulation in Bay of Fundy salt marshes: implications for restoration of reclaimed marshes. Global Biogeochem Cycles 15:943-954, doi:10.1029/2000GB001346

Cornell JA, Craft CB, Megonigal JP (2007) Ecosystem gas exchange across a created salt marsh chronosequence. Wetlands 27:240-250

$>$ Craft C, Megonigal P, Broome S, Stevenson J and others (2003) The pace of ecosystem development of constructed Spartina alterniflora marshes. Ecol Appl 13: 1417-1432

> Davy AJ, Brown MJH, Mossman HL, Grant A (2011) Colonization of a newly developing salt marsh: disentangling independent effects of elevation and redox potential on halophytes. J Ecol 99:1350-1357

$>$ de Groot AV, Veeneklaas RM, Bakker JP (2011) Sand in the salt marsh: contribution of high-energy conditions to salt-marsh accretion. Mar Geol 282:240-254

de Visser SN, Freymann BP, Olff H (2011) The Serengeti food web: empirical quantification and analysis of topological changes under increasing human impact. J Anim Ecol 80:484-494

> Dijkema KS (1990) Salt and brackish marshes around the Baltic Sea and adjacent parts of the North Sea: their vegetation and management. Biol Conserv 51:191-209

> Duarte CM, Middelburg JJ, Caraco N (2005) Major role of marine vegetation on the oceanic carbon cycle. Biogeosciences 2:1-8

> Elschot K, Bouma TJ, Temmerman S, Bakker JP (2013) Effects of long-term grazing on sediment deposition and salt-marsh accretion rates. Estuar Coast Shelf Sci 133: 109-115

Esselink P, Petersen J, Arens S, Bakker JP and others (2009) Salt marshes, Thematic Report No. 8. In: Marencic H, de Vlas J (eds) Quality Status Report 2009, Wadden Sea Ecosystem No. 25. Common Wadden Sea Secretariat, Trilateral Monitoring and Assessment Group, Wilhelmshaven

First MR, Hollibaugh JT (2010) Environmental factors shaping microbial community structure in salt marsh sediments. Mar Ecol Prog Ser 399:15-26

Hemminga MA, de Leeuw J, de Munck W, Koutstaal BP (1991) Decomposition in estuarine salt marshes: the effect of soil salinity and soil water content. Vegetatio 94: 25-33

Janzen HH (2004) Carbon cycling in earth systems - a soil science perspective. Agric Ecosyst Environ 104:399-417

Jobbágy E, Jackson R (2000) The vertical distribution of soil organic carbon and its relation to climate and vegetation. Ecol Appl 10:423-436

Jones CG, Lawton JH, Shachak M (1994) Organisms as ecosystem engineers. Oikos 69:373-386

Kerbes RH, Kotanen PM, Jefferies RL (1990) Destruction of wetland habitats by lesser snow geese: a keystone species on the west coast of Hudson Bay. J Appl Ecol 27:242-258

Kiehl K, Eischeid I, Gettner S, Walter J (1996) Impact of different sheep grazing intensities on salt marsh vegetation in northern Germany. J Veg Sci 7:99-106

Kirwan ML, Mudd SM (2012) Response of salt-marsh carbon accumulation to climate change. Nature 489:550-553

Knapp AK, Briggs JM, Collins SL, Archer SR and others (2008) Shrub encroachment in North American grasslands: shifts in growth form dominance rapidly alters control of ecosystem carbon inputs. Glob Change Biol 14: 615-623

Kuijper DPJ, Bakker JP (2005) Top-down control of small herbivores on salt-marsh vegetation along a productivity gradient. Ecology 86:914-923

Laffoley Dd'A, Grimsditch G (eds) (2009) The management of natural coastal carbon sinks. International Union for Conservation of Nature (IUCN), Gland

- Le Quéré C, Raupach MR, Canadell JG, Marland G and others (2009) Trends in the sources and sinks of carbon dioxide. Nat Geosci 2:831-836

> Leendertse PC, Roozen AJM, Rozema J (1997) Long-term changes (1953-1990) in the salt marsh vegetation at the Boschplaat on Terschelling in relation to sedimentation and flooding. Plant Ecol 132:49-58

Lovelock CE, Adame MF, Bennion V, Hayes M, O'Mara J, Reef R, Santini NS (2014) Contemporary rates of carbon sequestration through vertical accretion of sediments in mangrove forests and saltmarshes of south east Queensland, Australia. Estuaries Coasts 37:763-771

Lunstrum A, Chen L (2014) Soil carbon stocks and accumulation in young mangrove forests. Soil Biol Biochem 75: 223-232

Madsen J (1991) Status and trends of goose populations in the western Palearctic in the 1980s. Ardea 79:113-122

Mcleod E, Chmura GL, Bouillon S, Salm R and others (2011) A blueprint for blue carbon: toward an improved understanding of the role of vegetated coastal habitats in sequestering $\mathrm{CO}_{2}$. Front Ecol Environ 9:552-560

> McNaughton SJ, Banyikwa FF, McNaughton MM (1998) Root biomass and productivity in a grazing ecosystem: the Serengeti. Ecology 79:587-592 
Middelburg JJ, Nieuwenhuize J (1998) Carbon and nitrogen stable isotopes in suspended matter and sediments from the Schelde Estuary. Mar Chem 60:217-225

Mokany K, Raison RJ, Prokushkin AS (2006) Critical analysis of root:shoot ratios in terrestrial biomes. Glob Change Biol 12:84-96

Morris JT, Jensen A (1998) The carbon balance of grazed and non-grazed Spartina anglica saltmarshes at Skallingen, Denmark. J Ecol 86:229-242

Nieuwenhuize J, Maas YEM, Middelburg JJ (1994) Rapid analysis of organic carbon and nitrogen in particulate materials. Mar Chem 45:217-224

Nolte S, Müller F, Schuerch M, Wanner A, Esselink P, Bakker JP, Jensen K (2013) Does livestock grazing affect sediment deposition and accretion rates in salt marshes? Estuar Coast Shelf Sci 135:296-305

Olff H, de Leeuw J, Bakker JP, Platerink RJ, van Wijnen HJ (1997) Vegetation succession and herbivory in a salt marsh: changes induced by sea level rise and silt deposition along an elevational gradient. J Ecol 85:799-814

Olsen YS, Dausse A, Garbutt A, Ford H, Thomas DN, Jones DL (2011) Cattle grazing drives nitrogen and carbon cycling in a temperate salt marsh. Soil Biol Biochem 43: 531-541

Osland MJ, Spivak AC, Nestlerode JA, Lessmann JM and others (2012) Ecosystem development after mangrove wetland creation: plant-soil change across a 20-year chronosequence. Ecosystems 15:848-866

R Development Core Team (2011) R: a language and environment for statistical computing. $\mathrm{R}$ Foundation for Statistical Computing, Vienna. Available at www.rproject.org

Saintilan N, Rogers K, Mazumder D, Woodroffe C (2013) Allochthonous and autochthonous contributions to carbon accumulation and carbon store in southeastern Australian coastal wetlands. Estuar Coast Shelf Sci 128: 84-92

Schrama M, Berg MP, Olff H (2012) Ecosystem assembly rules: the interplay of green and brown webs during salt marsh succession. Ecology 93:2353-2364

Schrama M, Heijning P, Bakker JP, van Wijnen HJ, Berg MP, Olff H (2013) Herbivore trampling as an alternative pathway for explaining differences in nitrogen mineralization in moist grasslands. Oecologia 172:231-243

Sjögersten S, van der Wal R, Woodin SJ (2008) Habitat type determines herbivory controls over $\mathrm{CO}_{2}$ fluxes in a warmer arctic. Ecology 89:2103-2116

Sjögersten S, van der Wal R, Woodin SJ (2012) Impacts of grazing and climate warming on C pools and decomposition rates in arctic environments. Ecosystems 15:349-362

Sun M, Aller RC, Lee C, Wakeham S (2002) Effects of oxygen and redox oscillation on degradation of cell-associated lipids in surficial marine sediments. Geochim Cosmochim Acta 66:2003-2012

Taylor DI, Allanson BR (1993) Impacts of dense crab popula-

Editorial responsibility: Just Cebrian,

Dauphin Island, Alabama, USA tions on carbon exchanges across the surface of a salt marsh. Mar Ecol Prog Ser 101:119-129

- Thomas CD, Cameron A, Green RE, Bakkenes M and others (2004) Extinction risk from climate change. Nature 427: 145-148

Valery L, Bouchard V, Lefeuvre JC (2004) Impact of the invasive native species Elymus athericus on carbon pools in a salt marsh. Wetlands 24:268-276

> van Bochove E, Beauchemin S, Theriault G (2002) Continuous multiple measurement of soil redox potential using platinum microelectrodes. Soil Sci Soc Am J 66: 1813-1820

van de Koppel J, Huisman J, van der Wal R, Olff H (1996) Patterns of herbivory along a productivity gradient: an empirical and theoretical investigation. Ecology 77 : 736-745

van der Wal R, Lieshout S, Bos D, Drent RH (2000) Are spring staging Brent geese evicted by vegetation succession? Ecography 23:60-69

> van der Wal R, Sjögersten S, Woodin SJ, Cooper EJ and others (2007) Spring feeding by pink-footed geese reduces carbon stocks and sink strength in tundra ecosystems. Glob Change Biol 13:539-545

van Straalen NM, Rijninks PC (1982) The efficiency of Tullgren apparatus with respect to interpreting seasonalchanges in age structure of soil arthropod populations. Pedobiologia 24:197-209

> van Wijnen HJ, Bakker JP (1997) Nitrogen accumulation and plant species replacement in three salt marsh systems in the Wadden Sea. J Coast Conserv 3:19-26

van Wijnen HJ, Bakker JP (2001) Long-term surface elevation change in salt marshes: a prediction of marsh response to future sea-level rise. Estuar Coast Shelf Sci 52:381-390

- Veeneklaas RM, Dijkema KS, Hecker N, Bakker JP (2013) Spatio-temporal dynamics of the invasive plant species Elytrigia atherica on natural salt marshes. Appl Veg Sci 16:205-216

Wanner A, Suchrow S, Kiehl K, Meyer W, Pohlmann N, Stock M, Jensen K (2014) Scale matters: impact of management regime on plant species richness and vegetation type diversity in Wadden Sea salt marshes. Agric Ecosyst Environ 182:69-79

Yu OT, Chmura GL (2009) Soil carbon may be maintained under grazing in a St Lawrence Estuary tidal marsh. Environ Conserv 36:312-320

> Zehetner F, Lair GJ, Gerzabek MH (2009) Rapid carbon accretion and organic matter pool stabilization in riverine floodplain soils. Global Biogeochem Cycles 23: GB4004, doi:10.1029/2009GB003481

Zimmerman RC, Kohrs DG, Alberte RS (1996) Top-down impact through a bottom-up mechanism: the effect of limpet grazing on growth, productivity and carbon allocation of Zostera marina L. (eelgrass). Oecologia 107: 560-567

Submitted: June 10, 2014; Accepted: July 31, 2015

Proofs received from author(s): September 23, 2015 